\title{
Lembaga perkreditan desa sebagai penopang ke-ajegan budaya ekonomi masyarakat Bali
}

\author{
Anak Agung Ngurah Gede Sadiartha \\ Universitas Hindu Indonesia \\ Email: bungapucuk@yahoo.com
}

\begin{abstract}
Village Credit Union "Lembaga Perkreditan Desa" (LPD) continues to develop into an autonomous and tough intermediary institution. This paper discusses LPD as a model of superior traditional financial institutions, and its role in supporting the economic culture of the people of Bali. This paper is the result of qualitative research with data obtained from observation, documentation study and interview with 10 informants: LPD credit recipients, practitioners and observers of LPD. The data were descriptively, qualitatively, and interpretatively analyzed using economic management theory and the theory of social practice (Bourdieu). The results show: Firstly, LPD develops into a formidable traditional financial institution because: (a) LPD was autonomous, not subject to central policy, but refer to local regulations and awig-awig; (b) Implementation of modern global banking management, ie management functions, 5C principles, and innovation of LPD products and implementastion of cultural values of local organizations including Hindu philosophy on prosperity Tri Hita Karana, Catur Asrama and human relations manyamebraya. Secondly, the existence of LPD was able to improve socio-economic welfare and sustain the cultural traditions of indigenous villagers in Bali.
\end{abstract}

Keywords: Village Credit Union, economic culture, Balinese society.

\begin{abstract}
Abstrak
Lembaga Perkreditan Desa (LPD) terus berkembang menjadi lembaga intermediasi yang otonom dan tangguh. Makalah ini membahas LPD sebagai model lembaga keuangan tradisional yang unggul, dan perannya dalam menopang ke-ajegan budaya ekonomi masyarakat Bali. Makalah ini merupakan hasil penelitian kualitatif yang datanya diperoleh dari hasil observasi, studi dokumentasi dan wawancara
\end{abstract}


dengan 10 informan: penerima kredit LPD, praktisi dan pemerhati LPD. Analisis data dilakukan secara deskriptif kualitatif-intepretatif dengan menerapkan teori manajemen ekonomi dan teori praktik sosial (Bourdieu). Hasil penelitian menunjukkan: Pertama, LPD berkembang menjadi lembaga keuangan tradisional yang tangguh karena (a) LPD bersifat otonom, tidak tunduk pada kebijakan pusat, tetapi mengacu kepada Perda dan awig-awig; (b) menerapkan manajemen perbankan modern global, yakni fungsi-fungsi manajemen, prinsip 5C, dan inovasi produk LPD, serta menerapkan nilai-nilai Budaya Organisasi lokal, termasuk filsafat Hindu tentang kesejahteraan Tri Hita Karana, dan human relation, manyamebraya. Kedua, keberadaan LPD mampu meningkatkan kesejahteraan sosial-ekonomi dan menopang ke-ajegan tradisi-budaya masyarakat desa pakraman di Bali.

Kata kunci: LPD, budaya ekonomi, masyarakat Bali.

\section{Pendahuluan}

Secara umum, kebijakan pembangunan pedesaan dapat dipilah Smenjadi tiga kelompok. Pertama, kebijakan yang secara tidak langsung mengarah pada sasaran tetapi memberikan dasar suasana yang mendukung tercapainya kegiatan sosial ekonomi masyarakat desa seperti penyediaan sarana dan prasarana pendukung, penyempurnaan peraturan perundang-undangan yang menunjang kegiatan sosial ekonomi masyarakat. Kedua, kebijakan yang secara langsung mengarah pada kegiatan sosial ekonomi kelompok sasaran, seperti halnya sandang, pangan, perumahan, pendidikan, dan kesehatan. Ketiga, kebijakan khusus yang menyangkut masyarakat melalui upaya khusus, dengan melakukan kegiatan ekonomi sesuai dengan budaya setempat (Rintuh, 2005: 55).

Berbagai daerah di Indonesia telah mengembangkan lembaga keuangan sesuai budaya setempat. Lembaga keuangan lokal itu, misalnya, Badan Kredit Kecamatan (BKK) di Jawa Tengah yang didirikan tahun 1970, serta Lembaga Perkreditan Kecamatan (LPK) Jawa Barat dan Lumbung Pitih Nagari (LPN) Sumatra Barat yang keduanya didirikan Tahun 1972 (Arsyad 2008: 72), dan Lembaga Perkreditan Desa (LPD) didirikan tahun 1984.

Pengembangan BKK di Jawa Tengah, LPK di Jawa Barat, serta 
lembaga keuangan sejenis di daerah lain didasari oleh kebijakan pemerintah pusat, yakni SKB tiga menteri dan Gubernur Bank Indonesia 2009 dan Undang-Undang RI Nomor 1 tahun 2013 tentang Lembaga Keuangan Mikro (LKM). Hal ini berbeda dengan LPD yang pendiriannya didasari oleh Peraturan Daeran Provinsi Bali (No. 8 tahun 2012) serta kebijakan lokal (awig-awig). Sesuai dasar pendiriannya ini, maka LPD sebagai lembaga keuangan milik desa pakraman bersifat unik dan otonom, tidak tunduk pada kebijakan pemerintah pusat dan hanya mengacu pada kebijakan lokal yang diorientasikan untuk menguatkan kehidupan ekonomi dan sosial-budaya masyarakat adat di Bali.

Dalam kurun waktu lebih dari dari30 tahun, sejak pendiriannya tahun 1984, LPD telah menunjukkan perkembangan yang sangat pesat, baik dari sisi jumlah maupun dari sisi perkembangan usahanya. LPD yang dicetuskan dan didirikan oleh Gubernur Bali, Ida Bagus Mantra (1978-1988), kini telah berkembang dengan pesat. Pada awal pendirian, tahun 1984/1985, hanya ada 8 unit LPD, sampai akhir tahun 2016 telah menjadi 1433 unit LPD tersebar di suluruh desa pakraman di Bali. Total aset LPD mencapai Rp 15,5 trilyun, melibatkan pengurus dan karyawan LPD sebanyak 7.882 orang (LP-LPD Provinsi Bali, 2017).

LPD mampu menempatkan dirinya sejajar dengan LKM lainnya, termasuk dalam hal standar pelayanan dan profesionalitas pengelola LPD. LPD terus meningkatkan pelayanan dan profesionalitas karyawannya, antara lain dengan melakukan langkah strategis, yakni mendirikan laboratorium sistem informasi Mikro Banking-LPD ON LINE untuk meningkatkan nilai LPD di mata stakeholder. Langkah strategis untuk meningkatkan pelayanan LPD diharapkan mampu menjadi tumpuan bagi pemberdayaan ekonomi rakyat, di samping mendorong laju pertumbuhan ekonomi masyarakat desa di Bali (Profil LPD, 2009).

LPD terus dikembangkan menjadi lembaga keuangan milik desa pakraman yang kuat dan sehat. Akan tetapi, tidak semua LPD memiliki kinerja keuangan yang sehat. Sampai periode 31 Desember 2014, jumlah LPD dengan kategori sehat sebanyak 994 LPD 69,85\%) dan kategori cukup sehat sebanyak 133 LPD (9,35\%). Sisanya sebanyak 79 LPD (5,55\%) berada pada kategori tidak 
sehat (termasuk 135 LPD dalam keadaan macet). Bila dibadingkan dengan periode 31 Desember 2013, jumlah LPD dalam kategori sehat mengalami penurunan sebanyak 20 LPD (1,97\%), namun LPD kategori cukup sehat mengalami kenaikan sebanyak 17 LPD $(14,66 \%)$. Jumlah LPD dalam kategori kurang sehat mengalami menurunan sebanyak 11 LPD (12,22\%) dan LPD tidak sehat mengalami kenaikan sebanyak 15 LPD (7,43\%). Adanya LPD yang macet dan LPD yang tidak sehat akibat kurang taatnya penerapan sistem manajemen, dan penyaluran kredit kurang hati-hati memerlukan perhatian tersendiri. LPD-LPD bersama stakeholders terkait perlu bekerja keras dalam menjaga prestasi LPD yang sudah sehat, serta melakukan pembenahan kepada LPD yang tidak sehat agar menjadi lebih sehat. Kesehatan LPD adalah indikator bahwa LPD tersebut bisa terus dikembangkan karena akan memberikan kontribusi yang positif bagi pengembangan perekonomian krama serta penguatan bagi desa pakraman setempat (BKS-LPD, 2015).

Sebagaimana yang dinyatakan Dendawijaya (2005: 14), LPD secara umum telah menjadi lembaga intermediasi, yakni sebagai menghimpun dan menyalurkan dana masyarakat di suatu wilayah desa pakraman. LPD diharapkan mampu menumbuhkan wirausaha rakyat dan mendukung eksistensi dan pembangunan desa pakraman setempat. Hal ini sesuai dengan cita-cita pencetusnya, Prof Mantra (almr) tahun 1980-an, LPD diharapkan menjadi instrument pembangunan yang berupaya membangun masyatakat Bali dengan "kepribadian", yakni pembangunan yang berupaya mengentaskan masyarakat Bali dari masalah kemiskinan, sekaligus menjadi penopang dalam pelestarian seni-budaya dan tradisi masyarakat Hindu Bali (Sadiartha, 2016).

Sebagai lembaga keuangan milik desa pakraman, LPD diharapkan terus eksis bahkan mampu berkembang dan bersaing dengan lembaga perbankan umum sejenis. LPD tetap berakar pada tradisi budaya masyarakat Bali, namun juga mampu beradaptasi dan berinovasi mengikuti trend manajemen budaya perbankan modern. Hal ini dimungkinkan karena LPD memiliki Budaya Organisasi yang unggul. Makalah ini membahas dua hal: (1) Mengapa LPD berkembang menjadi model lembaga keuangan milik desa pakraman yang unggul?, (2) Bagaimana LPD menjadi 
penopang ke-ajegan budaya ekonomi masyarakat Bali?

\section{Kajian pustaka}

Sesuai dengan topik yang dikaji dalam karya tulis ini, ada sejumlah hasil kajian LPD sebelumnya. Kajian dimaksud menyangkut perkembangan LPD, peranan LPD dalam penguatan sosial-ekonomi masyarakat Bali, strategi, potensi dan pengembangan LPD di masa depan. Perkembangan LPD telah dijelaskan dalam buku berjudul Cetak Biru Lembaga Perkreditan Desa (2009). Buku ini mendiskripsikan hasil survei tentang citra LPD. Survei yang melibatkan 369 nasabah LPD pada 84 LPD di Bali ini menyimpulkan: (1) Prosedur simpanpinjam LPD cukup mudah dan cepat; (2) jaminan yang diperlukan untuk memperoleh pinjaman di LPD terjangkau; (3) tingkat suku bunga yang diberikan merupakan salah satu faktor yang memegang peranan penting bagi nasabah LPD; (4) lokasi LPD relatif dekat dengan tempat tinggal krama desa setempat; (5) sebagian besar nasabah merasa aman menyimpan dananya di LPD.

Giriarta dalam buku berjudul Jejak Langkah LPD Desa Adat Pecatu (2009), menyebutkan bahwa selama 21 tahun perjalanan Lembaga Perkreditan Desa (LPD) Desa Adat Pecatu telah mengalami berbagai kemajuan, baik dari sisi pertumbuhan aset maupun laba yang diperoleh. Walaupun pada tahun pertama harus merugi, LPD Desa Adat (Pakraman) Pecatu yang didirikan dengan modal awal sebesar Rp 4.857.575,00, maka sampai November 2009 LPD Desa Adat Pecatu pesat berkembang dengan aset yang mencapai Rp 128.605.767.881,00 dan laba Rp 4.082.984.491,00. Pertumbuhan laba tersebut selanjutnya dikembalikan kepada warga (krama) Desa Pecatu dalam bentuk dana pembangunan sebesar 20 persen dan dana sosial sebesar lima persen. Di samping itu, LPD Desa Adat Pecatu juga mengeluarkan produk-produk yang disesuaikan dengan kebutuhan krama desa adat tersebut, selain turut berperan dalam memberdayakan dan meningkatkan kesejahteraan krama secara sekala (nyata) dan niskala (taknyata/ spiritual). Peran serta LPD Pecatu dalam melaksanakan upacara ngaben dan nyekah massal di Desa Adat Pecatu (Tahun 2006 dan 2009).

LPD harus eksis dalam persaingan bisnis dewasa ini. Dalam kaitan ini, Cendikiawan (2006) dalam penelitiannya berjudul 
“Eksistensi Lembaga Perkreditan Desa (LPD) Desa Pakraman Mas Ubud Gianyar, Sudi Potensi dan Kendala", menyatakan bahwa langkah strategis yang dilakukan LPD Desa Pakraman Mas Ubud Gianyar untuk tetap eksis di tengah persaingan LKM di Kabupaten Gianyar adalah dengan meningkatkan fungsi petugas penarik simpanan dan petugas kredit supaya target yang ditetapkan bisa tercapai. Selain itu, sumber daya manusia sebagai komponen penggerak perlu juga ditingkatkan kualitasnya yakni dengan memberikan pelatihan-pelatihan di bidangnya masing-masing. Kebijakan adat yang berupa awig-awig digunakan untuk menekan krama. Selain itu, potensi bendesa pakraman serta prajuru desa pakraman yang berperan besar dalam mengarahkan krama agar sepakat mengembangkan LPD Desa Pakraman Mas, yaitu dengan menyosialisasikan program-program LPD.

LPD telah mendukung usaha para nasabahnya. Dalam kaitan ini, Yoni (2006) menulis tesis berjudul "Peran Serta Lembaga Perkreditan Desa (LPD) Desa Pakraman Ubung, Denpasar dalam Menunjang Kewirausahaan Nasabahnya: Perspektif Kajian Budaya". LPD di Desa Pakraman Ubung memberikan kredit usaha kecil (KUK) kepada nasabahnya. Dengan demikian, arus perdagangan sektor usaha kecil di Desa Pakraman Ubung dapat berjalan dengan baik dan meningkatkan pendapatan masyarakat. LPD Desa Pakraman Ubung juga mampu meningkatkan rasa solidaritas sosial antar krama Desa Ubung, di samping mampu menopang kehidupan spiritual.

Peran LPD dalam mengembangkan usaha krama juga disebutkan dalam buku yang ditulis oleh Sadiartha berjudul Hegemoni dan Kontra Hegemoni Pengelolaan Lembaga Perkreditan Desa (2016). Dalam kajian ini disimpulkan bahwa LPD terbukti mampu memberdayakan krama desa pakraman setempat. Kontribusi LPD kepada desa pakraman diharapkan untuk meningkatkan keterampilan krama desa pakraman dalam upaya membentuk jiwa kewirausahaan, sehingga tujuan didirikan LPD untuk mendorong pertumbuhan dan pemerataan ekonomi dapat diwujudkan.

LPD tetap eksis dan berkembang karena memiliki budaya organisasi yang unggul. Terkait hal ini, Windia menulis jurnal berjudul "Analisis Bisnis yang Berlandaskan Tri Hita Karana; Sebuah 
Kasus Pelaksanaan/Penjabaran PIP Kebudayaan Unud" (2007). Disebutkan bahwa LPD memiliki Budaya Organisasi yang unggul sehingga LPD siap berkompetisi dengan lembaga perbankan lainnya. Keberadaan, pengelolaan dan pengembangan LPD yang didasari oleh nilai-nilai filosofi Hindu tentang tiga penyebab kesejahteraan, Tri Hita Karana (THK), menjadikan LPD memiliki Budaya Organisasi yang cukup tangguh. Budaya Organisasi LPD berbasis THK dapat menjadi sumber daya yang unik dalam penciptaan keunggulan kompetitif dalam memenangkan persaingan bisnis secara berkelanjutan.

Beberapa publikasi terkait LPD di atas menjadi referensi yang berharga untuk penyusunan karya ilmiah ini. Karya ilmiah ini merupakan hasil penelitian kualitatif yang datanya diperoleh dari hasil observasi, studi dokumentasi dan wawancara mendalam dengan 10 informan, yaitu penerima kredit LPD, pengelola LPD Desa Adat Kuta dan LPD Desa Adat Kerobokan dan pengurus Lembaga Pemberdayaan LPD Provinsi Bali. Analisis data dilakukan secara deskriptif kualitatif-intepretatif dengan menerapkan teori manajemen ekonomi dan teori praktik sosial (Bourdieu). Hasil kajian ini diharapkan menjadi bagian dari publikasi tentang eksistensi lembaga keuangan tradisional (LPD) sebagai bagian dari model budaya ekonomi yang memberdayakan masyarakat adat di Bali.

\section{LPD sebagai model lembaga keuangan milik desa Pakraman yang unggul}

Budaya Organisasi Lembaga Perkreditan Desa (LPD) lahir, tumbuh dan berkembang berawal dari kearifan lokal (local genius) yang dimiliki oleh masyarakat Hindu Bali. Secara historis LPD dicetuskan oleh Prof. Dr. Ida Bagus Mantra pada tahun 1980-an. Kendati pendirian LPD baru terlaksana pada tahun 1984, akan tetapi embrio LPD telah ada, berakar, dan dipraktikkan dalam kehidupan masyarakat desa pakraman di Bali, yaitu berupa sekehesekehe, termasuk sekaa teruna-teruni (kelompok muda-mudi), sekaa gong (kelompok kesenian). Sekehe adalah kelompok sosial atau perkumpulaan yang dibentuk oleh anggota masyarakat adat menurut alasan, fungsi, dan tujuan tertentu (Koentjaraningrat, 
2007: 228).

Hampir di setiap desa pakraman memiliki sekehe seperti sekehe semal (perkumpulan berburu tupai) sekaa gong (perkumpulan pemain alat musik tradisional Bali) dan banyak lagi sekaa yang lain. Sekaa memiliki potensi untuk diberikan sentuhan administrasi dan perangkat kekinian untuk dikembangkan menjadi lembaga keuangan untuk menyejahterakan masyarakat dalam skala yang lebih luas. Menurut Geriya (2008:71) konsep sekaa merupakan ikatan kesatuan kelompok-kelompok yang memiliki kepentingan khusus, terwujud sebagai organisasi, kemudian dipadukan dengan aspek kelembagaan adat yang ada di desa pakraman. Adanya potensi, yakni berupa ikatan kesatuan kelompok masyarakat desa pakraman inilah yang kemudian mendasari pendirian Lembaga Perkreditan Desa (LPD).

Nilai-nilai budaya yang terkandung dalam organisasi sekaa antara lain (a) nilai gotong-royong (kebersamaan), (b) nilai kerja sama, (c) nilai disiplin untuk mencapai tujuan bersama, serta (d) nilai saling menguntungkan diantara anggotanya. Pekerjaan yang semula berat, bisa dipikul secara bersama-sama, sehingga keuntungan bersama pun diperoleh (sagilik saguluk, saluluk sabayantaka). Pendirian dan pengelolaan LPD yang digali dari kearifan lokal dan kultural masyarakat Bali yang berbasis pada kebersamaan, kekeluargaan dan kegotong-royongan, serta saling menguntungkan yang dicetuskan oleh Prof. Ida Bagus Mantra sejak tahun 1980-an. Budaya Organisasi LPD yang berakar dalam keberadaan organisasi tradisional sekaa paling tidak memiliki dua nilai yang mendasarinya, yakni (1) pang pade ngelahang, yakni semangat memiliki (sense of belonging) krama desa terhadap kebedaaan LPD di desa pakramannya. Semua krama desa setempat merasa memiliki dan berupaya ikut andil dalam mengembangkan LPD di desanya; (2) pang pade payu, artinya sama-sama laku, samasama untung, bisa diterima, hidup dan berkembang. Keberadaan LPD turut menghidupkan aktivitas perekonomian masyarakat desa setempat yang dalam praktiknya terdiri dari beraneka usaha, termasuk berdagang sembako, produk kerajinan, alat upacara (canang), pedagang kaki lima. Semua usaha ini bisa hidup, berkembang dan saling menguntungkan. 
Dasar hukum pendirian LPD dibentuk berdasarkan atas Peraturan Daerah Provinsi Bali Nomor 4 Tahun 2012 tentang Lembaga Perkreditan Desa serta kebijakan lokal (awig-awig) di setiap desa pakraman di Bali. Dengan dasar pendiriannya ini, maka keberadanLPD tidaktergantungdengankebijakantentang Lembaga Keuangan Mikro (LKM) yang lahir pada tahun 2013. Sebagai local genius, status LPD adalah otonom, menjadi lembaga keuangan tradisional milik desa pakraman yang memiliki memiliki Budaya Organisasi tersendiri. Sebagaimana konsep yang dikemukakan Schein (2004), Budaya Organisasi merupakan asumsi dasar, nilainilai, keyakinan, perilaku dan sikap bersama yang dianut organisasi yang dijadikan acuan dalam memahami lingkungan internal dan ekternal demi tercapainya tujuan organisasi.

LPD memiliki elemen Budaya Organisasi yang unggul. Sebagaimana kata Deal dan Allan (1982), terdapat lima elemen penentu budaya organisasi unggul, yakni: (1) LPD sebagai lembaga keuangan milik desa pakraman di Bali memiliki lingkungan dan pangsa pasar tersendiri sehingga bisa terus survive; (2) LPD memiliki jaringan cultural, yakni desa pakraman di Bali. Jaringan kultural ini bertindak sebagai "carrier", sistem nilai yang menopang keberadaan dan pengembangan organisasi LPD; (3) Adanya figur panutan dalam organisasi LPD adalah pada prajuru adat, penglisir sebagai sosok atau personifikasi dari sistem nilai dan menjadi contoh-teladan bagi pengelola LPD; (4) Tata cara kerja dan ritual merupakan program rutin dan sistematik kehidupan organisasi; dan (5) Sistem nilai merupakan konsep dan keyakinan dasar sebuah organisasi. Sistem nilai ini merupakan standar prestasi dan menentukan kesuksesan organisasi, nilai-nilai tersebut termasuk Tri Hita Karana yang bisa dijadikan patokan untuk kemajuan LPD. Melalui LPD, desa pakraman di Bali bisa mengaktualisasikan tiga prinsip hubungan keseimbangan hidup menuju kesejahteraan, Tri Hita Karana (THK), yakni hubungan manusia dengan Tuhan (parahyangan), manusia dengan sesamanya (pawongan) dan manusia dengan lingkungan alamnya (palemahan) (Mantra, 1996).

Sebagai bagian dari "lembaga perbankan", LPD dioperasionalkan dengan "manajemen glokasi", yakni manajemen perbankan modern global di satu sisi, tetapi di sisi yang lain 
tetap memegang teguh prinsip-prinsip budaya organisasi lokal. Prinsip - prinsip budaya organisasi lokal ini antara lain tercermin dalam: Pertama, penerapan nilai-nilai Budaya Organisasi Hindu, termasuk Tri Hita Karana, dan prinsip kepemimpinan Asta Brata. Kedua, pendekatan human relation "manyemabraya" dalam melayani nasabah LPD. Praktik human relation "manyamabraya" adalah budaya pelayanan yang mengedepankan hubungan dan kerjasama atas dasar persaudaraan, kesetaraan, saling membantu dan saling menguntungkan (Sadiartha, 2016). Human Relations merupakan inti dari sikap dan perilaku pegawai yang bekerja dengan baik dan benar (Rosyad dkk., 2012:2). Ketiga, berjalannya kepemimpinan tradisional dalam organisasi LPD. Sebagai organisasi keuangan milik desa pakraman, pemegang kekuasaan tertinggi LPD berada di tangan Bendesa Adat sebagai ceminan kewenangan yang dimiliki sebagai representasi pimpinan sekelompok krama desa pakraman atau satu desa pakraman. Pemerintah sengaja melibatkan bendesa adat sebagai pengawas internal LPD agar legitimasi keberadaan LPD di desa pakraman semakin kuat. Di bawah pengawas internal adalah pengurus inti dan staf LPD. Pengurus inti LPD terdiri atas ketua, sekretaris dan bendahara. Pengurus LPD memiliki tugas mengkoordinir staf LPD dan bertanggung jawab dalam pengelolaan LPD serta mempertanggungjawabkan pelaksanaan tugasnya kepada paruman desa melalui Pengawas LPD.

Sebagai lembaga keuangan, LPD dijalankan dengan tetap memegang teguh budaya kepemimpinan tradisional, disamping dioperasionalkan dengan manerapkan prinsip-prinsip dan manajemen perbankan modern. Prinsip-prinsip perbankan modern antara lain tercermin dalam: (1) penerapan prinsip 5C (Character, Capacity, Capital, Collateral, dan Condition of Economic) dalam mengantispasi kredit macet, (2) inovasi produk LPD, serta (3) implementasi fungsi-fungsi manajemen perbankan modern. Sesuai teori manajemen Henry Fayol (dalam Safroni, 2012), pengurus LPD melakukan fungsi-fungsi manajemen meliputi perencanaan (planning), pengorganisasian (organizing), pengarahan (commanding), pengkoordinasian (coordinating), pengendalian (controlling) sehingga tujuan organisasi LPD bisa tercapai (Sadiartha, 2016) 
LPD di Bali tetap eksis, berkembang dan mampu bersaing dengan bank-bank komersial umum lainnya, maka LPD melakukan inovasi-inovasi untuk memberikan pelayanan yang berkualitas kepada krama Desa setempat. LPD terus mengembangkan kemampuan manajerialnya, termasuk melaksanakan strategi manyamabraya dalam membangun wirausaha nasabahnya.

\section{LPD sebagai penopang keajegan budaya ekonomi masyaraat Bali}

LPD terus tumbuh dan berkembang menjadi lembaga intermediasi, yakni sebagai pengumpul sekaligus penyalur dana masyarakat desa pakraman di Bali. Keberadaan LPD secara umum tujuannya LPD adalah untuk menyimpan dan menyalurkan dana kepada krama desa di daerah lingkup LPD tersebut. Selain itu, LPD memiliki beberapa tujuan khusus yaitu: (a) mendorong pembangunan ekonomi masyarakat desa melalui kegiatan menghimpun tabungan dan deposito dari krama desa; (b) memberantas ijon, gadai gelap, dan lain-lain; (c) menciptakan pemerataan kesempatan berusaha dan perluasan kesempatan kerja bagi krama desa; dan (d) meningkatkan daya beli dan melancarkan lalu lintas pembayaran dan peredaran uang desa (Biro Hukum Setda Prov Bali, 2010).

LPD telah berkembang sebagai motor pembangunan desa pakraman. Dalam kaitan ini, I Nyoman Arnaya, selaku Ketua LP LPD Provinsi Bali menjelaskan bahwa LPD memiliki tujuan ganda. Di satu sisi, LPD didirikan untuk membangun dan memperkokoh perekonomian masyarakat desa pakraman. Di sisi lain LPD juga memperkuat dan menjaga adat dan budaya masyarakat Bali yang berlandaskan ajaran Agama Hindu. Upaya memperoleh keuntungan ekonomi secara optimal (aset LPD yang terus berkembang) bukanlah tujuan utama LPD. Tujuan utama LPD adalah tetap tegaknya keberlanjutan (ke-ajegan) budaya ekonomi krama Bali. Ke-ajegan budaya ekonomi adalah merupakan tindakan yang mencoba menghadirkan kemasalaluan untuk menjawab tantangan kekinian maupun masa depan (Kumbara 2010:20). Kemasalaluan dipahami sebagai nilai-nilai budaya organisasi sekaa sebagai cikal bakal wacana kelahiran LPD yang memiliki nilai gotong-royong, manyama braye, pade ngelahan dan pang pade payu, 
dengan demikian pemahaman keajegan budaya ekonomi adalah sebagai aktivitas transaksi keuangan yang berlandaskan nilai-nilai sekaa sebagai budaya Bali serta hasil keuntungan dikembalikan guna memperkuat nilai-nilai luhur yang ada di desa pakraman yang terkait dengan Tri Hita Karana. Dalam menjaga keberlanjutan budaya ekonomi masyarakat Bali secara nyata diwujudkan, antara lain melalui penyaluran dana pembangunan $20 \%$ dan dana sosial lima persen dari keuntungan LPD, serta dukungan LPD dalam menyediakan pendanaan (pinjaman kredit) kepada krama untuk mengembangkan usaha ekonominya.

Grafik 1. Total Aset, Tabungan, Deposito dan Kredit LPD Se-Bali Tahun 2011 dan 2016

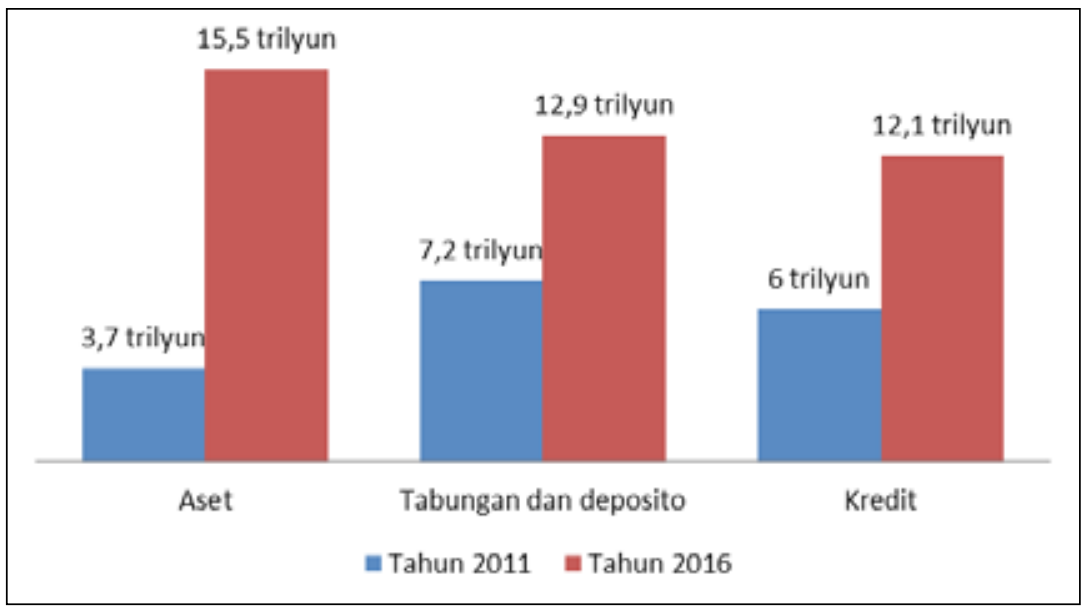

(Sumber: LP-LPD Provinsi Bali, 2017)

Grafik 1 menunjukkan bahwa jumlah aset, tabungan dan deposito yang dikumpulkan LPD dan kredit yang disalurkan LPD menunjukan peningkatan yang signifikan. Secara kumulatif, total aset LPD se-Bali tahun 2011 sebanyak kurang lebih 3,7 trilyun rupiah meningkat menjadi sekitar 15,5 trilyun rupiah pada tahun 2016. Jumlah simpanan masyarakat dalam bentuk deposito dan tabungan di LPD se-Bali pada tahun 2011 mencapai sekitar 7,2 trilyun rupiah meningkat menjadi kurang lebih 12,9 trilyun rupiah pada tahun 2016. Begitu pula total kredit yang disalurkan LPD seBali pada tahun 2011 kurang lebih 6 trilyun rupiah kepada 422 ribu 
nasabah, maka pada tahun 2016 total kredit yang disalurkan LPD sebanyak kurang lebih 12,1 triliun rupiah, dengan jumlah nasabah sebanyak 457 ribu orang (LP-LPD Provinsi Bali 2017).

Menurut Ketua BKS-LPD Provinsi Bali, I Nyoman Cendikiawan, Kredit LPD telah mendukung pengembangan wirausaha masyarakat Bali di pedesaan. Wirausaha ekonomi yang dikembangkan masyarakat Bali antara lain diwujudkan dengan membuka toko seni, warung sembako, toko asesoris, dan suvenir. Selain itu, wirausaha masyarakat juga berbentuk pedagang kaki lima dan berjualan di kios-kios pasar-pasar tradisional di seluruh desa pakraman di Bali. LPD telah menguatkan kehidupan ekonomi, sosial dan budaya masyarakat desa pakraman setempat (Yoni, 2005; Sadiartha, 2011).

Sebagian permodalan (kredit) yang dikelola LPD sengaja digelontorkan untuk membantu modal usaha krama di pasarpasar tradisional seluruh Bali. Di antara krama desa pakraman yang memperoleh dukungan permodalan dari LPD adalah krama Desa pakraman Kuta yang berjualan di Pasar Seni Kuta, Kecamatan Kuta dan krama Desa pakraman Kerobokan yang berjualan di Pasar Taman Sari, Kerobokan, Kecamatan Kuta Utara Kabupten Badung. Kedua pasar tradisional di pusat aktivitas pariwisata Kuta ini memang dikelola oleh desa pakraman setempat. Para pedagang yang berjualan di Pasar Taman Sari Kerobokan mendapatlan modal usaha dari LPD Desa Adat Kerobakan, sedangkan ratusan pedagang di Pasar Seni Kuta mendapatkan dukungan permodalan (kredit usaha) dari LPD Desa Adat Kuta.

Foto 1: Pasar Seni Kuta

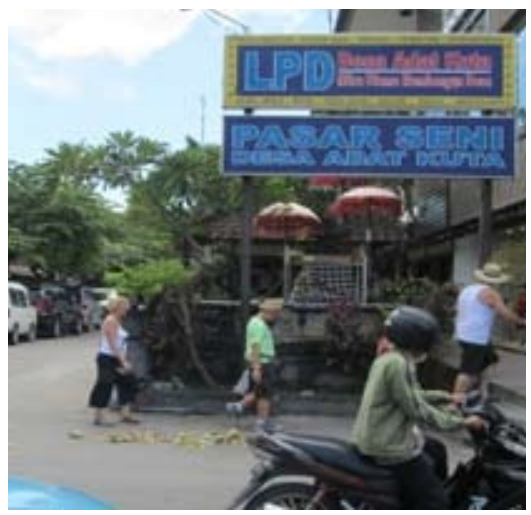

Foto 2: Pasar Tamansari Kerobogan

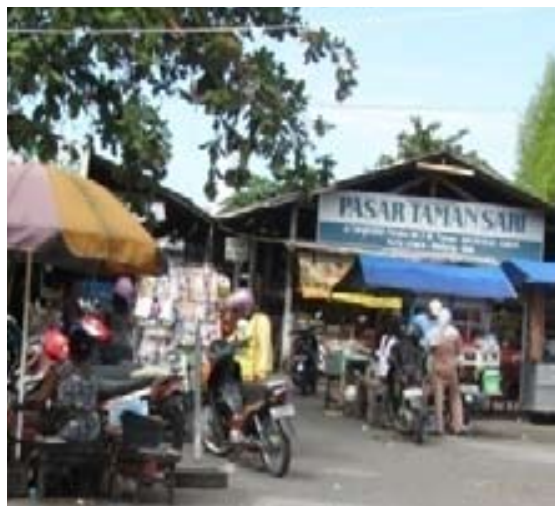

Sumber: Sadiartha, 2016 
Kepala LPD Desa Adat Kuta, I Wayan Gede Budha Artha menjelaskan bahwa penyaluran kredit LPD kepada masyarakat dilakukan dengan menerapkan prinsip kehati-hatian dan strategi manyamabraya, yakni melayani nasabah LPD atas dasar kebersamaan, persaudaraan, tolong menolong, saling memiliki (pangpadengelahang) saling mendukung dan saling menguntungkan (pangpade payu). Strategi menyamebraya telah berhasil membangun kepuasan dan loyalitas para nasabahnya.

Seperti bank-bank komersial umum lainnya, LPD berupaya memberikan pelayanan yang memuaskan krama desa setempat, termasuk proses pencairan kredit yang relatif cepat. Proses kredit yang cepat menjadikan LPD sangat disenangi oleh masyarakat, sehingga kebutuhan masyarakat desa setempat yang mendesak dapat teratasi. Strategi pencairan kredit LPD yang relatif cepat telah menguatkan citra postif LPD bagi krama desa setempat (Sadiartha, 2016).

LPD Desa Adat Kuta dan LPD Desa Adat Kerobokan telah mampu menopang penguatan adat, budaya dan kehidupan sosial masyarakat Bali. LPD berperan dalam mengatasi permasalahan masyarakat desa pakraman di Bali. Selain itu, LPD juga membantu mengatasi masalah fundamental masyarakat pedesaan di Bali yakni pendidikan dan kesehatan. Banyak LPD di Bali kini yang mengembangkan usahanya tidak saja dari aspek ekonomi semata tetapi juga berperan memberdayakan masyarakat melalui produkproduk inovatif LPD dalam mendorong pembangunan bidang pendidikan dan kesehatan. Di Bidang pendidikan sejumlah LPD telah mengemas "produk tabungan pendidikan" dan memberikan santunan beasiswa pendidikan secara rutin bagi anak-anak dari krama desa setempat. Selanjutnya di bidang kesehatan, sejumlah LPD di Bali juga membuat produk dana kesehatan bagi masyarakat desa.

Selain itu, melalui pemanfaatan keuntungan LPD berupa dana pembangunan (20\%) dan dana sosial (5\%), LPD mampu menggairahkan kehidupan adat-keagamaan, kegiatan seni-budaya dan olah raga krama desa setempat. Kegiatan upacara piodalan desa, kegiatan seni-budaya oleh sekaa gong, sekaa pesantian, serta kegiatan olah raga oleh anggota sekaa teruna-teruni bisa dijalankan berkat dukungan dana dari LPD (Sadiartha, 2011). 
Sesuai teori praktik sosial Bourdieu (1990), LPD telah menjadi modal budaya sekaligus sebagai modal ekonomi yang memberdayakan masyarakat Bali. Keberadaan dan perkembangan LPD telah menguatkan seni-budaya dan tradisi masyarakat Hindu Bali. Berkat dukungan dana sosial dan dana pembangunan hasil keuntungan LPD, beragam seni kerajian, seni-budaya rakyat Bali (yang tergabung dalam sekehe gong, sekaa pesantian) serta kehidupan adat-keagamaan masyarkat Hindu Bali di tiap-tiap desa pakraman dapat dikembangkan.Keberadaan LPD dewasa ini tetap pada jati diri kediriannya, membesarkan dan menguatkan induknya, yaitu desa pakraman setempat yang melaksanakan Tri Hita Karana. Dalam kaitan ini, para pemimpin dan pengelola LPD di Bali menerapkan ajaran kepemimpinan Hindu, termasuk Astha Brata sehingga budaya organisasi LPD dapat dimanifestasikan untuk memperkuat kehidupan masyarakat desa pakraman, baik dalam kontek parahyangan (hubungan Manusia dengan Sang Hyang Widi Wasa/Tuhan), pawongan (keharmonisan hubungan antarsesama manusia) dan palemahan (keharmonisan hubungan manusia dengan lingkungannya). LPD mampu menopang keberlanjutan (keajegan) tradisi budaya masyarakat Hindu Bali.

\section{Simpulan dan saran}

Lembaga Perkreditan Desa (LPD) merupakan lembaga keuangan tradisional yang otonom yang pendiriannya didasarkan kepada kebijakan lokal, yakni peraturan daerah dan awig-awig desa setempat. LPD telah menjadi lembaga intermediasi yang efektif dalam mengumpulkan dan menyalurkan kredit intuk mengembangkan wirausaha krama desa pakraman setempat. LPD merupakan lembaga keuangan tradisional milik desa pakraman yang tangguh karena bersifat otonom dan dikontruksi oleh nilainilai Budaya Organisasi yang unggul. Di satu sisi, LPD dibangun dan dibesarkan dengan tetap memegang teguh nilai-nilai Budaya Organisasi masyarakat Bali yang berbasiskan ajaran Hindu, di sisi yang lain LPD dioperasionalkan dengan nilai budaya, prinsip dan sistem manajemen perbankan modern. LPD mampu menguatkan kehidupan sosial, meningkatkan kesejahteraan ekonomi, mengokohkan sendi-sendi budaya tradisional dan menopang keajegan tradisi-budaya masyarakat Desa pakraman di 
Bali.

Keberadaan LPD telah berhasil membangun kewirausahaan masyarakat desa pakraman perlu terus dilanjutkan bahkan dikembangkan dalam kreativitas dan inovasi produk serta diharapkan tetap mengokohkan sendi-sendi Agama Hindu, adat, dan budaya.

\section{Daftar pustaka}

Arsyad, lincolin, 2008. Lembaga Keuangan Mikro Institusi, Kinerja, dan Sustanabilitas. Yogyakarta: ANDI

Bourdieu, Pierre. 1990. (Habitus X Modal) + Ranah= Praktik: Pengantar Paling Komprehensif kepada Pemikiran Bourdieu (terjemahan). Bandung: Jalasutra.

BKS-LPD. 2015. Standar Kerja Organisasi dan Manajemen SDM LPD Bali. Denpasar: BKS-LPD.

Cendikiawan, I Nyoman. 2006. "Eksistensi Lembaga Perkreditan Desa (LPD) Desa Pakraman Mas Ubud Gianyar (Studi Potensi dan Kendala)." Denpasar: Program Magister Ilmu Agama dan Kebudayaan, UNHI Denpasar.

Deal, Terrence E and Allan A Kennedy. 1982. Corporate Culture, The Rites and Ritual of Corporate Life. New York: Addition - Wesley Publishing Inc.

Dendawijaya, Lukman. 2005. Manajemen Perbankan (Edisi Kedua). Jakarta: Ghalia Indonesia.

Geriya, I Wayan. 2008. Transformasi Kebudayaan Bali Memasuki Abad XXI. Surabaya: Paramita.

Keputusan Bersama Menteri Keuangan, Menteri Dalam Negeri, Menteri Koperasi dan UKM, dan Gubernur Bank Indonesia, dengan Nomor: 351.1/KMK.010/2009, Nomor: 009-639 A Tahun 2009, Nomor: 01/SKB/M.KUKM/2009, dan Nomor: 11/43A/ KEP.GBI/2009, tanggal 7 September 2009, tentang Strategi Pengembangan Lembaga Keuangan Mikro.

Koentjaraningrat. 2007. Villages in Indonesia. Jakarta: Equinox Publishing. 
Kumbara, Anak Agung Anom. 2010. Konstruksi Wacana Ajeg Bali Dalam Relasi Kuasa: Antara Ideologi dan Utopia. Pidato Pengenalan Jabatan Guru Besar Tetap Dalam Bidang Ilmu Epistimologi Antropologi pada Fakultas Sastra Universitas Udayana. Jimbaran: Universitas Udayana.

LP-LPD. 2017. Neraca Lembaga Perkreditan Desa periode 2011 - 2016. Denpasar: LP-LPD.

Mantra, Ida Bagus. 1996. Landasan Kebudayaan Bali. Denpasar: Yayasan Dharma Sastra.

Pemerintah Provinsi Bali. 2010. Profile Lembaga Perkreditan Desa (LPD) Daerah Bali Tahun 2009.Denpasar: Pemerintah Provinsi Bali.

Pemerintah Provinsi Bali. 2002. Peraturan Daerah Provinsi Bali Nomor 8 Tahun 2002 tentang Lembaga Perkreditan Desa (LPD).

Perda Provinsi Bali Nomor 4 Tahun 2012 tentang Lembaga Perkreditan Desa (LPD).

Profil Lembaga Perkreditan Desa (LPD) Daerah Bali Tahun 2008. Denpasar: Pemerintah Provinsi Bali.

Sadiartha, Anak Agung Ngurah Gede. 2011. “Hegemoni Pemerintah Dalam Pengelolaan Lembaga Perkreditan Desa (LPD) Di Kabupaten Badung." Denpasar: Program Pascasarjana Universitas Udayana Denpasar.

Sadiartha, Anak Agung Ngurah Gede. 2016. "Implementation of Tri Hita Karana - Based Organizational Culture by Lembaga Perkreditan Desa at Kuta Traditional Village." Discovery, Vol. 52, No. 252, December 1, 2016, pp. 2331-2338..

Sadiartha, Anak Agung Ngurah Gede. 2016. Hegemoni dan Kontra Hegemoni Pengelolaan Lembaga Perkreditan Desa. Denpasar: Universitas Hindu Indonesia (UNHI) Denpasar.

Safroni, Ladzi. 2012. Manajemen dan Reformasi Pelayanan Publik dalam Konteks Birokrasi Indonesia. Yogyakarta: Aditya Media Publishing.

Schein, E. 2004. Organizational cultureand leadership. Published by Jossey-Bass A WileyImprint. 
Rintuh, Cornelis dan Miar. 2005. Kelembagaan dan Ekonomi Rakyat. Yogyakarta: BPFE Yogyakarta.

Rosyad, Soleh dkk. 2012. Pengaruh Human Relation Terhadap Prestasi Kerja Pegawai Dinas Pendapatan Dan Pengelolaan Keuangan Daerah Di Kabupaten Lebak, E-Jurnal Management, Volume 1 Nomor 2, Tahun 2012, hlm., 2.

Undang-Undang Pemerintah RI No. 1 Tahun 2013 tentang Lembaga Keuangan Mikro (LKM)

Windia, W. 2007. "Analisis Bisnis yang Berlandaskan Tri Hita Karana; Sebuah Kasus Pelaksanaan/Penjabaran PIP Kebudayaan UNUD", Wahana, 57, 4-6.

Yoni, I Gusti Ayu. 2005. "Peran Serta Lembaga Perkreditan Desa (LPD) Desa Parakyatn Ubung, Denpasar dalam Menunjang Kewirausahaan Nasabahnya: Perspektif Kajian Budaya" Tesis. Denpasar: Universitas Udayana. 